\title{
Management of Ring Womb with Twining of Foetuses in Corriedale Ewe: A Case Report
}

\author{
Touqeer Ahmed ${ }^{1 *}$, Savleen Kour ${ }^{2}$ and Zul-I-Huma ${ }^{2}$
}

${ }^{1}$ Division of Animal Reproduction Gynaecology and Obstetrics, ${ }^{2}$ Division of Veterinary

Medicine Faculty of Veterinary Sciences and Animal Husbandry, Sher-e-Kashmir University

of Agricultural Sciences and Technology of Jammu, R.S. Pura, Jammu, 181102,

Jammu and Kashmir, India

*Corresponding author

\section{A B S T R A C T}

Keywords

Dystocia, Ewes,

Ringwomb,

Secondary uterine

inertia, Twins

Article Info

Accepted:

05 April 2020

Available Online:

10 May 2020
The present case report explains a case of dystocia due to ringwomb and its treatment in an adult Corriedale ewe, which was presented to the clinic with a history of straining and dystocia. Clinico-vaginal examination revealed cervix with 2 finger dialation, intact fetal membranes and two live foetuses. Taking into account the time from initiation of parturition, size, number and the life of the fetuses, it was decided to perform caesarian section to deliver both the fetuses alive. The ewe and both the lambs recovered uneventfully.

\section{Introduction}

Abnormality or difficulty in giving birth to the point of needing human intervention is referred to as dystocia (Youngquist et al., 2007; Blood et al., 2011). Ringwomb or failure of the cervix to dilate at the time of parturition remains one of the major causes of dystocia in ewes (Ahmed et al., 2015; Upasana et al., 2019).
Dystocia in sheep can be due to poor maternal pelvic conformation, an oversized fetus, lamb malpresentation, uterine inertia in polytocous ewes, vaginal prolapse, ringwomb, uterine torsion, and ectopic pregnancy (Brozoset al., 2012).

Prolonged dystocia results in necrotic metritisin ewes and is usually fatal (Scott, 2005; Brozos et al., 2012). A delay in treatment of dystocia increases the risk of 
losing the lambs, as well as the ewe. This short communication describes a case of twinning and ringwomb followed by uterine inertia in a Corriedale ewe that resulted in dystocia. In addition, the clinic-pathological findings and the therapeutic approach with caesarean section are described.

\section{History}

An adult Corriedaleewe weighing $30 \mathrm{~kg}$ was presented to the TVCC, SKUAST-J, with the history of difficulty in giving birth. The last parturition of the animal also resulted into dystocia due to twins and the fetuses were delivered by applying traction. The process of parturition had commenced about 12hours before presentation to the hospital.

Clinico-vaginal examination revealed that the cervix was dilated about 2 fingers and the fetal membranes were intact. The ewe was straining and restless due to abdominal discomfort, without any abdominal contractions. Fetal examination revealed that there were two foetuses and both the fetuses were alive. Taking into account the size and number of fetuses and narrowed diameter of the birth canal, there was no possibility for vaginal delivery. So it was decided to perform caesarian section to deliver the fetuses.

\section{Treatment and management procedure}

The ewe was administered ceftriaxone @10 $\mathrm{mg} / \mathrm{kg}$, intramuscularly (IM) and meloxicam $@ 0.5 \mathrm{mg} / \mathrm{kg}$ intravenously (IV) 1 hour prior to surgery. Then ewe was administered diazepam hydrochloride slowly @ $0.5 \mathrm{mg} / \mathrm{kg}$ body weight intravenously and IV fluid line (5\% DNS) was established. The ewe was restrained in right lateral recumbency. Local anaesthesia was achieved by infiltrating $2 \%$ lignocaine $\mathrm{HCl} @ 4.5 \mathrm{mg} / \mathrm{kg}$ (Lignocaine and Adrenaline injection, Intas Pharmaceuticals Ltd, India) using the linear infiltration. After the anaesthesia, $7 \mathrm{~cm}$ long incision was made through the ventral paramedian line (in between lineaalba and subcutaneous abdominal vein), a sharp incision was made into subcutaneous tissues then abdominus rectus muscles and peritoneum were incised. After exteriorisation the uterine horns, a longitudinal incision was made on the greater curvature of the left uterine horn starting at upper third to uterine bifurcation through which the first foetus was extracted after that the second foetus was located and extracted from the same incision. The suturing of the uterine incision was done with chromic catgut No. 1 in two layers using continuous cushing and lamberts pattern respectively. Abdominal muscles were sutured in a continuous pattern with chromic catgut No. 2.The skin was sutured using braided silk No.1 in a horizontal mattress pattern.

Postoperatively, ceftriaxone (0.5 g, BID, IM) for five days and meloxicam $(0.5 \mathrm{mg} / \mathrm{kg}, \mathrm{OD}$, IM) for three days were prescribed. Antiseptic dressing using $5 \%$ povidine iodine was continued twice daily till suture removal on 14 days post- operation. The animal along with both the lambs were found healthy and active 25 days post-operation.

Dystocia is defined as difficulty in giving birth and may lead to the death of dam and new born due to trauma and excessive manipulation of birth canal (Sharun and Erdogan, 2019). Dystocia mainly occurs due to maternal and fetal causes (Sharun and Erdogan, 2019; Balamurugan and Mohanapriya, 2020). Maternal causes include small pelvic size, ring womb, uterine inertia and fetal causes are malposition, feto-pelvic disparity, fetal emphysema and ascites (Ahmed et al., (2017). Ring womb or incomplete cervical dilatation accounts for an incidence of 20 to $30 \%$ of all dystocia cases in ewe and doe (Abdullah et al., 2015).Some studies have reported that ring womb 
condition is associated with factors like age, low calcium level, phosphorus deficiency and low glucose level (Sharun and Erdogan., 2019).

Figure.1 Management of Dystocia in a ewe: (A,B) Preparation of site the operation site. (C) Exteriorised uterine horn containing the foetus. (D) Removal of the foetus from the uterus. (E) Suturing of the uterus. (F) Suturing of the skin. (G) Two live and healthy newborn lambs. (H) Dam after completion of the surgery. (I) Newborn lamb sucking on the Dam
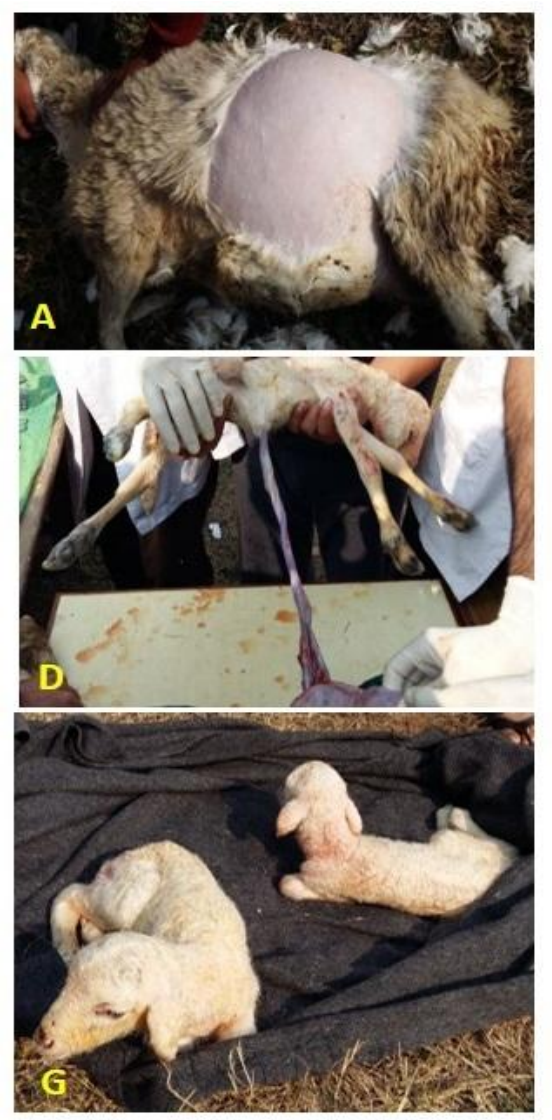
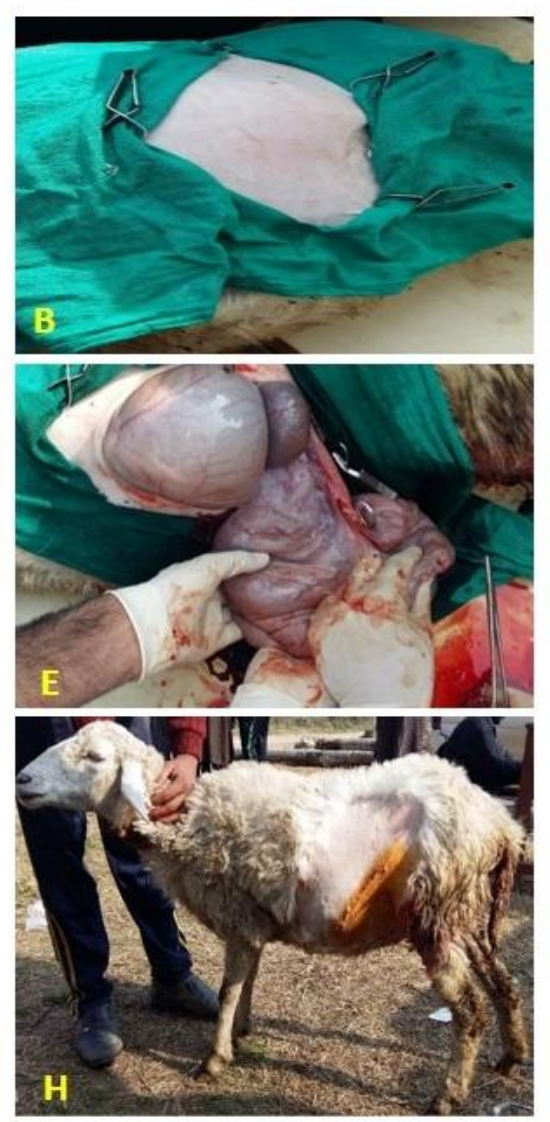
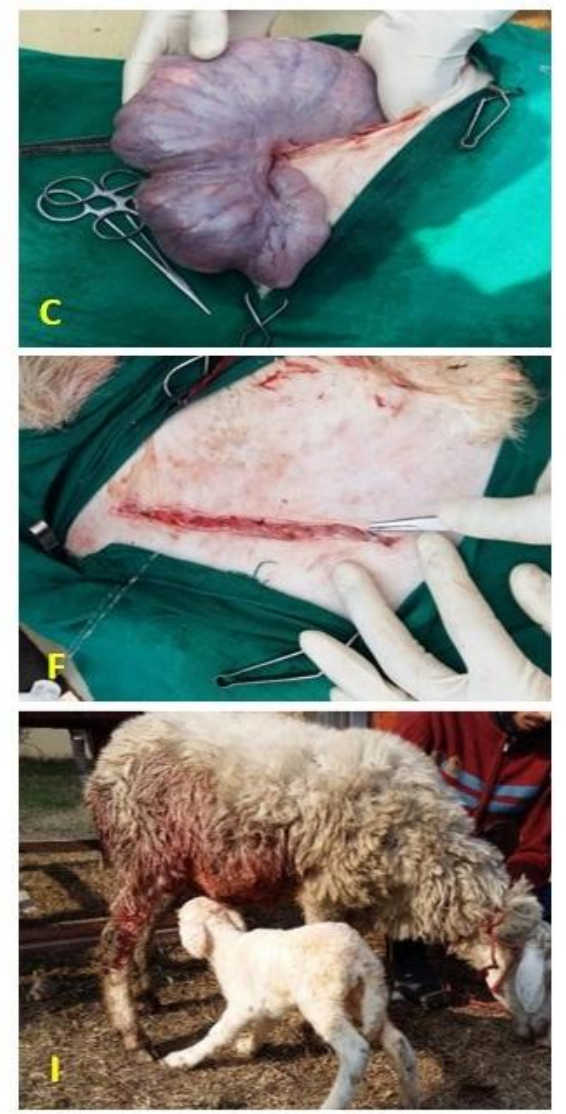

C-section is needed in obstructive dystocia, accompanied by shock or systemic illness, uterine inertia, prolonged active labour or failure in medical management (Abdullah et al., 2015). The techniques of C-section mainly ventral midline, paramedian and left flank method are preferred in small ruminants (Smith, 2008). Ventral midline and paramedian approach is superior to left flank method due to less post-operative complications (intraoperative haemorrhages and tissue reactions) (Ennen et al., 2013). Even though ventral midline and paramedian approach is superior, it requires general anaesthesia and proper casting of animal (Abubakar et al., 2014). The anaesthetic technique also include local infiltration of lignocaine hydrochloride as line block or paravertebral block depending upon the site of surgery (Fubini and Ducharme, 2004). Csection has a satisfactory outcome for both the dam and the new born animal (Ismail, 2017).

Obstetrical emergencies in small ruminants require effective management and timely corrections. Management of obstetrical emergencies not only involves saving the life of dam and offspring but also conserves future breeding soundness of the animal. 


\section{References}

Abdullah, F.F.J., Chung, E.L.T., Sadiq, M.A., Abba, Y., Tijjani, A., Mohammed, K., Osman, A.Y. and Laila, M.A.M. 2015. Management of fetal dystocia in ewe: A case report. J. Adv. Vet. Anim. Res. 2(2): 225-228.

Abubakar, A.A., Andeshi, R.A., Yakubu, A.S., Lawal, F.M. and Adamu, U. 2014. Comparative Evaluation of Midventral and Flank Laparotomy Approaches in Goat. J. Vet. Med. 2014.

Ahmed, A., Balarabe, A.T., Jibril, A., Sidi, S., Jimoh, A.A. and Gobe, R.M. 2017. Incidence and Causes of Dystocia in Small Ruminants in Sokoto Metropolis, Northwestern, Nigeria. Sch. J. Agric. Vet. Sci. 4(3):114-8.

Ahmed, T., Malik, A.A., Lone, F.A., Khatun, A. and R. Islam. 2015. Dystocia due to Unilateral Shoulder Flexion with Downward Deviation of Head in Ewe - A Case Report. Theriogenology Insight, 5(3): 199-201.

Balamurugan, N. and Mohanapriya, T. 2020. Dystocia due to Conjoined Twin Foetus in a Non-descriptive Ewe. Int. J. Curr. Microbiol. App. Sci. 9(1): 938-940.

Blood, D.C., Studdert, V.P. and Gay, C.C. 2011. Saunders Comprehensive Veterinary Dictionary (4th Edition). London: Saunders.

Brozos, C.N., Lazarides, L., Karagiannis, I., Kiossis, E., Tsousis, G., Psychas, V. and Giadinis, N. 2012. Prolonged dystocia, uterine necrosis, and ovariohysterectomy in a Chios ewe. Turk. J. Vet. Anim. Sci. 36(2):211-3.

Ennen, S., Scholz, M., Voigt, K., Failing, K. and Wehrend, A. 2013. Puerperal development of ewes following dystocia: a retrospective analysis of two approaches to caesarean section. Vet. Rec. 172(21): 554-554.

Fubini, S. L. and Ducharme, N. G. 2004 Farm animal surgery. Saunders. St. Louis.

Ismail, Z.B. 2017. Dystocia in sheep and goats: Outcome and fertility following surgical and non-surgical management. Mac. Vet. Rev. 40(1):91-6.

Scott, P.R. 2005. The management and welfare of some common ovine obstetrical problems in the United Kingdom. Vet. J. 170(1):33-40.

Sharun, K. and Erdogan, G. 2019. A Review: Obstetrical Emergencies in Small Ruminants. Alexandria J. Vet. Sci. 62(1):1-16.

Smith, M.C. 2008. Dystocia management and neonatal care. In Large animal. Proceedings of the North American Veterinary Conference, Volume 22, Orlando, Florida, USA, 312-314.

Upasana, C., Poyam, M.R. and Tiwari, R.P. 2019. Surgical Management of Ring Womb in Ewe. Theriogenology Insight, 9(1): 47-49.

Youngquist, R.S. and Threlfall, W.R. 2007. Current therapy in large animal theriogenology (2nd Edition). Elsevier Health Sciences.

\section{How to cite this article:}

Touqeer Ahmed, Savleen Kour and Zul-I-Huma. 2020. Management of Ring Womb with Twining of Foetuses in Corriedale Ewe: A Case Report. Int.J.Curr.Microbiol.App.Sci. 9(05): 680-683. doi: https://doi.org/10.20546/ijcmas.2020.905.075 